\title{
K-Ar biotite ages from Miocene post-collisional Garam Chashma leucogranite, eastern Hindukush Range (Trans-Himalayas), northwestern Pakistan
}

\author{
Mohammad ZafaR*, Mamoru MuratA*, Tahseenullah KHAN**, \\ Hiroaki OzAwA* and Hiroshi NisHimura* \\ *Department of Geosciences, Faculty of Science, Naruto University \\ of Education, Naruto, Tokushima 772-8502, Japan \\ **Geoscience Laboratory, Geological Survey of Pakistan, \\ Islamabad, Pakistan
}

\begin{abstract}
Garam Chashma granitic rocks intrude discordantly into the Hindukush metamorphic complex on the southern margin of the Asian plate, Trans-Himalayas, northwestern Pakistan. The rocks are fine to coarsegrained, two-mica leucogranite. $\mathrm{K}$-Ar biotite analyses of four samples from the Garam Chashma pluton yield 18-20 Ma ages. These ages are younger than those of the other post-collisional granitic rocks in Trans-Himalayas of Pakistan and resemble those of the Higher Himalayan granitic rocks.
\end{abstract}

\section{Introduction}

The collision of Indian and Asian plates that occurred around 55-40 Ma (Tahirkheli, 1982; Coward et al., 1986; Rowley, 1996) provoked one of the youngest orogenies in the world, the Himalayan orogeny. Following the collision, continual crustal shortening, thickening and metamorphic events resulted in the anatexis and emplacement of numerous plutons in the collision zone.

The ages of the pre-collisional continental plutons are well established by several authors (Desio et al., 1964; Searle et al., 1991). On the contrary, the post-collisional small and large plutons emplaced during Himalayan orogeny show a wide range of variation from 37 Ma to 1.4 Ma (Searle et al., 1989; Debon et al., 1987; Schneider et al., 1999a, b). It appears necessary to obtain more age data to understand the dynamotectonic igneous activities of the region, especially in the

M. Zafar, e9820107@ naruto-u.ac.jp

M. Murata, 村田 守, atarumm@naruto-u.ac.jp Corresponding author

T. Khan, tahseen@ geolab.isb.sdnpk.org

H. Ozawa，小澤大成，hiroaki@ naruto-u.ac.jp

H. Nishimura，西村 宏，naruto.hiroshi.nishimura@ nifty.ne.jp
Kohistan arc and adjacent areas. The present authors intend to report here the $\mathrm{K}-\mathrm{Ar}$ biotite ages of Garam Chashma pluton.

\section{Tectonic setting of the region}

In northern Pakistan, the main geologic units include Hindukush-Kararkoram (Trans-Himalayas), Nanga Parbat-Haramosh Massif (Higher Himalayas) and intercalated Kohistan-Ladakh paleo-island arc (Figure 1). The Northern Suture (NS) that separates the KohistanLadakh island arc from the Asian plate was developed in ca. $100 \mathrm{Ma}$ due to the closure of the Neotethys (Pudsey, 1986; Petterson and Windley, 1985). The arc is bounded in the south by Main Mantle Thrust (MMT), which formed as a result of India-Asia collision in 5540 Ma (Tahirkheli, 1982; Coward et al., 1986; Rowley, 1996).

In the Asian plate of northwestern Pakistan, majority of the granitoids in Hindukush metamorphic complex of Wakhan zone (Gaetani et al., 1996) are precollisional in nature. The Garam Chashma pluton is composed of the only noticeable post-collisional, Stype leucogranite (Zafar et al., 1998). 


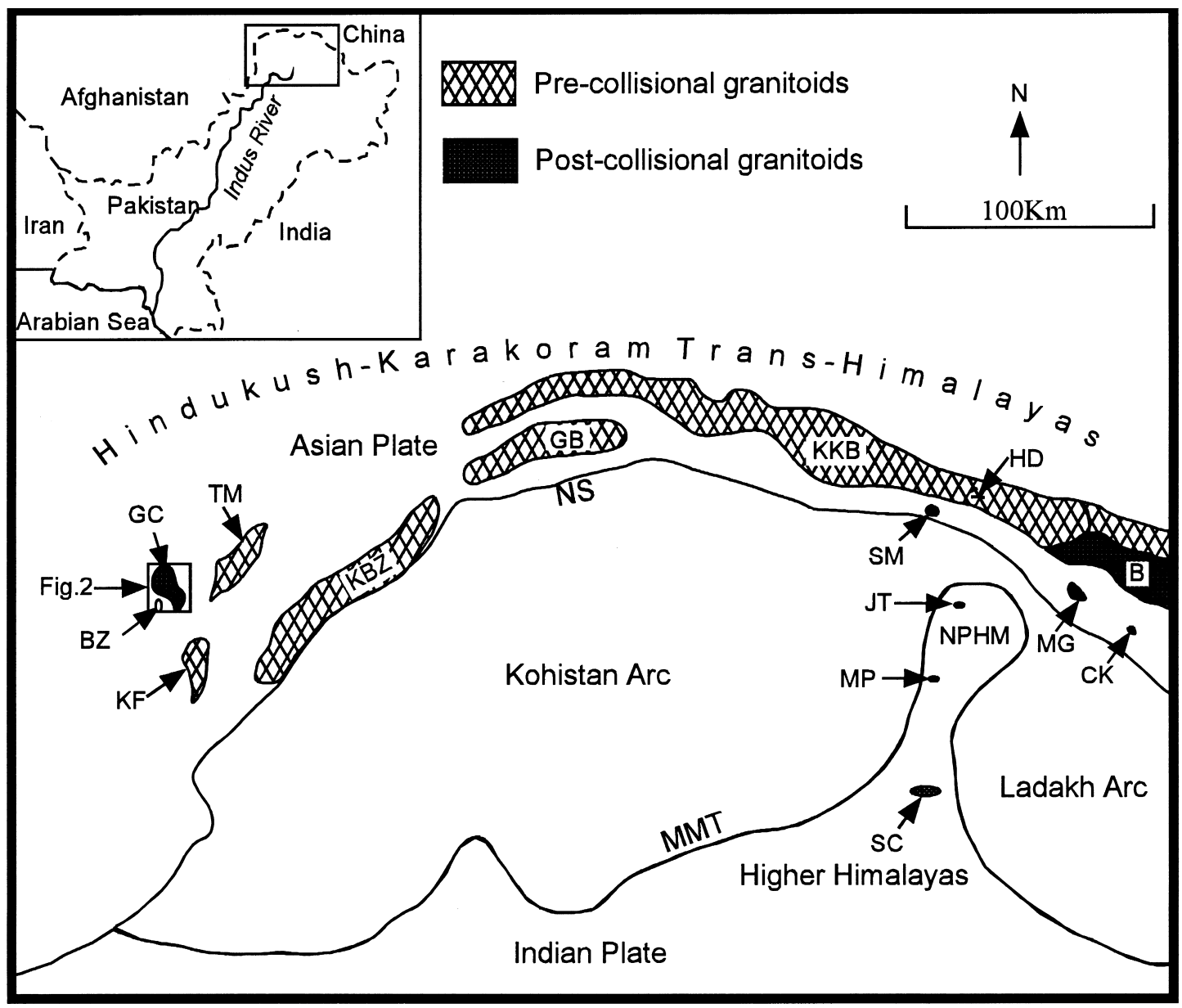

Figure 1. Geological sketch map of northern Pakistan (after Pudsey, 1986; Hildebrand et al., 1998; Schneider et al, 1999a, b). Inset shows location of the map. NS, Northern Suture; MMT, Main Mantle Thrust; NPHM, Nanga Parbat-Haramosh Massif; KKB, Karakoram batholith; GB, Ghamu Bar; KBZ, Kesu Buni Zom; TM, Tirich Mir; KF, Kafiristan; BZ, Birzine; GC, Garam Chashma; SM, Sumayar; HD, Hunza Dikes; MG, Mango Gusar; CK, Chingkang-la; B, Baltoro; JT, Jutial; MP, Mazeno Pass; SC, South Chichi.

\section{Geology of the Garam Chashma area}

\section{Pre-collisional granitoids}

The pre-collisional Tirich Mir (TM) and Kafiristan (KF) granitoids (Fig. 1) are located in the Hindukush metamorphic complex of Wakhan zone (Gaetani et al., 1996), which shows greenschist to amphibolite facies metamorphism. The pre-collisional granitic rocks are mainly hornblende-biotite granodiorites with $\mathrm{K}$-feldspar megacrysts ranging in size from several millimeters to a few centimeters. They are strongly foliated and are sometimes described as granodiorite gneisses (Khan, 1986). Rocks of the Tirich Mir pluton commonly have quartz and $\mathrm{K}$-feldspar augens. The Tirich Mir pluton yields $117 \pm 5 \mathrm{Ma} \mathrm{Rb}-\mathrm{Sr}$ (biotite) age (Desio et al., 1964), whereas, Kafiristan pluton gives $48 \pm 2 \mathrm{Ma} \mathrm{K}-\mathrm{Ar}$ (biotite) age (Searle, 1991). The $48 \pm 2 \mathrm{Ma}$ age of the
Kafiristan pluton may be an erroneous result, because field studies show strong deformation and effects of metamorphism suggesting its intrusion before the formation of the Northern Suture.

The Birzine pluton (BZ), exposed to the southwest of Garam Chashma (GC), is composed of fine to medium-grained granodiorite. The age of this pluton has not been determined yet, but strong deformation and foliation suggest its pre-collisional age. Major and trace element chemistry suggests that it is akin to the Kafiristan pluton (Zafar et al., 1998; Murata et al., 1999).

\section{Post-collisional Garam Chashma pluton}

The post-collisional Garam Chashma pluton is located about $30 \mathrm{~km}$ northwest of the Northern Suture, and covers an area of about $300 \mathrm{~km}^{2}$ (Fig. 2). It intrudes discordantly into the metasedimentary rocks and consists 


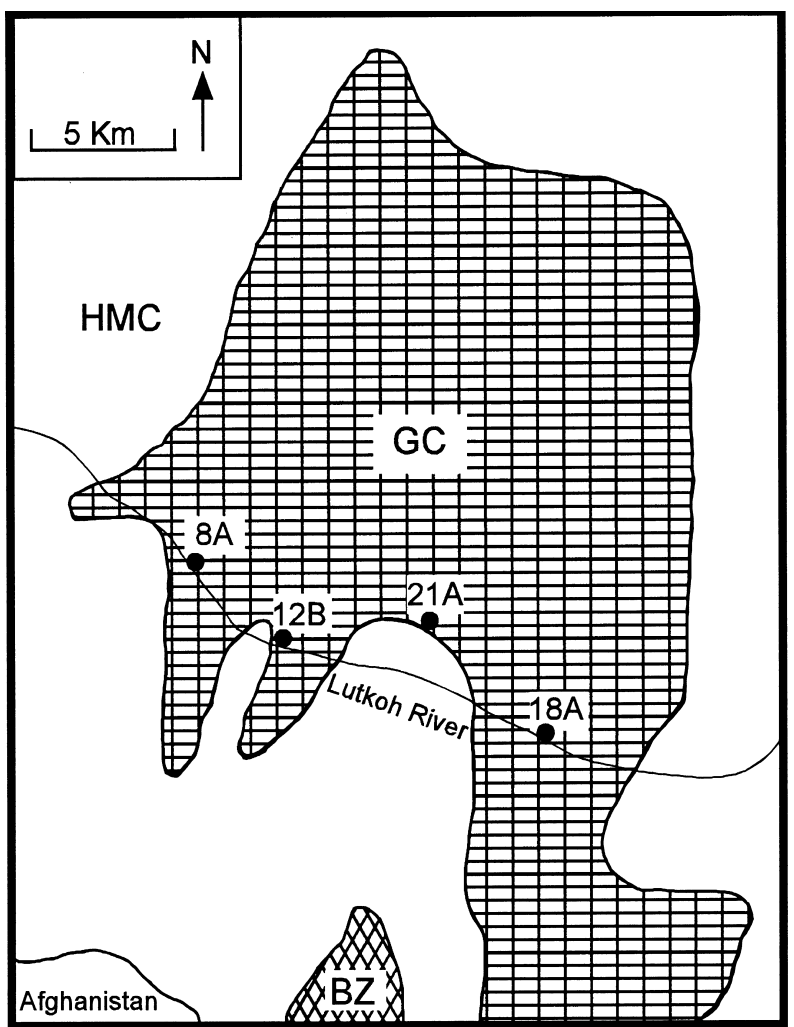

Figure 2. Geologic sketch map of the Garam Chashma area showing sample localities (modified after Khan, 1986). HMC, Hindukush Metamorphic Complex; GC, Garam Chashma; BZ, Birzine.

of fine to coarse-grained leucogranite with little change in lithofacies. It is generally massive, but shows foliation along the intrusive contacts. Aplitic and pegmatitic veins and/or dikes are widespread through the pluton. Hildebrand et al., (1998) reported U-Pb (monazite) age of $24 \pm 0.5 \mathrm{Ma}$ for the Garam Chashma leucograntie. They speculated that this age possibly represents crustal melting or the upper limit on the age of regional metamorphism.

\section{Petrography}

The Garam Chashma leucogranite is composed of muscovite, biotite, plagioclase, $\mathrm{K}$-feldspar and quartz with subordinate garnet and tourmaline. The ratio of biotite to muscovite is not constant. Muscovite is evenly distributed. It is also found as inclusions in plagioclase and $\mathrm{K}$-feldspar. Biotite is brown and contains inclusions of zircon and/or sillimanite. Plagioclase is euhedral to subhedral and contains inclusions of muscovite, biotite, and zircon. $\mathrm{K}$-feldspar is usually subhedral and contains abundant inclusions of muscovite, biotite, and zircon. Micrographic intergrowths of $\mathrm{K}$-feldspar and quartz are observed in aplitic rocks.
Quartz crystals are usually interstitial to both plagioclase and $\mathrm{K}$-feldspar. Subhedral to euhedral almandine garnet crystals are usually fractured and contain zircon inclusions. The skeletal frameworks in garnet contain quartz. No reaction rims of garnets are observed. A few scattered anhedral greenish crystals of tourmaline are also observed. Tourmaline shows light to dark green optical zonation and is devoid of any inclusions. Among the accessory minerals apatite is the most abundant. Other accessory minerals include zircon, sillimanite and allanite. Ilmenite and pyrrhotite are also observed.

\section{$\mathbf{K}-$ Ar age determination}

Four representative fresh samples were selected for $\mathrm{K}-\mathrm{Ar}$ age determination. The sampling sites are indicated in Figure 2. The samples were crushed in a mortar and sieved. Only 100-150 mesh size fractions were used to separate biotite by isodynamic magnetic separator. The biotite grains were further purified using heavy liquid (Thallium Formate-Malonate). Potassium was analyzed by flame photometry (Nagao et al., 1984). ${ }^{40} \mathrm{Ar}$ was determined by the isotope dilution method with ${ }^{38} \mathrm{Ar}$ spike using the mass spectrometer (Nagao and Itaya, 1988; Itaya et al., 1991) at the Hiruzen Institute for Geology and Chronology. $\mathrm{K}-\mathrm{Ar}$ age was calculated using the physical constants, $\lambda_{\mathrm{e}}=0.581 \times 10^{-10} / \mathrm{y}$, $\lambda_{\beta}=4.962 \times 10^{-10} / \mathrm{y},{ }^{40} \mathrm{~K} / \mathrm{K}=0.0001167$ (Steiger and Jäger, 1977). The results for Garam Chashma leucogranite range from 18.05 Ma to $19.85 \mathrm{Ma}$ (Table 1).

\section{Results and Discussion}

The $\mathrm{K}-\mathrm{Ar}$ biotite ages of $18-20 \mathrm{Ma}$ (Table 1 ) of the Garam Chashma leucogranite indicate that it is probably the youngest post-collisional granitic body in the Trans-Himalayas of northwestern Pakistan. A comparison of post-collisional granitoids in the Trans-and Higher Himalayas of the Pakistan, India and Nepal is given in Table 2.

In the Trans-Himalayas of northeastern Pakistan, the other known post-collisional granites yield ages from 21 to $37 \mathrm{Ma}$. These include Mango Gusar (MG), Chingkang-la (CK), Hunza dikes (HD), Sumayar (SM) and Baltoro (B) plutons (Fig. 1). The Mango Gusar pluton is composed of a non-foliated, medium-grained, two-mica granite-granodiorite and yields $\mathrm{U}-\mathrm{Pb}$ (zircon) age of $37 \pm 0.8 \mathrm{Ma}$ (R. Parrish data in Searle, 1991). The Chingkang-la pluton is composed of pyroxenehornblende-biotite granite with a $\mathrm{K}-\mathrm{Ar}$ (hornblende) age of $34 \pm 1.0 \mathrm{Ma}$ (Searle et al., 1989). The Baltoro 
Table 1. K-Ar biotite ages for Garam Chashma leucogranite

\begin{tabular}{lcccc}
\hline Sample No. & $\mathrm{K}(\mathrm{wt} \%)$ & $\begin{array}{c}\text { Rad. }{ }^{40} \mathrm{Ar} \\
\left(10^{-8} \mathrm{ccSTP} / \mathrm{g}\right)\end{array}$ & $\begin{array}{c}\mathrm{K}-\mathrm{Ar} \text { age } \\
(\mathrm{Ma})\end{array}$ & $\begin{array}{c}\text { Non. Rad. } \\
\operatorname{Ar}(\%)\end{array}$ \\
\hline $8 \mathrm{~A}$ & $7.109 \pm 0.142$ & $502.2 \pm 6.0$ & $18.11 \pm 0.42$ & 13.9 \\
& & $500.5 \pm 6.1$ & $18.05 \pm 0.42$ & 14.0 \\
$12 \mathrm{~B}$ & $7.118 \pm 0.142$ & $512.4 \pm 5.9$ & $18.46 \pm 0.42$ & 12.6 \\
& & $506.8 \pm 5.9$ & $18.26 \pm 0.42$ & 12.3 \\
$18 \mathrm{~A}$ & $6.933 \pm 0.139$ & $510.1 \pm 5.9$ & $18.86 \pm 0.43$ & 12.7 \\
& & $505.1 \pm 5.9$ & $18.68 \pm 0.43$ & 13.1 \\
$21 \mathrm{~A}$ & $6.733 \pm 0.135$ & $518.1 \pm 6.1$ & $19.72 \pm 0.46$ & 13.7 \\
& & $521.5 \pm 6.2$ & $19.85 \pm 0.46$ & 13.9 \\
\hline
\end{tabular}

Table 2. Post-collisional granitoids in the Trans-and Higher Himalayas of Pakistan, India and Nepal

\begin{tabular}{lll}
\hline & Rock Type & Age (Ma) \\
\hline $\begin{array}{l}\text { Trans-Himalayas } \\
\text { Garam Chashma pluton (this study) }\end{array}$ & Two-mica leucogranite & $18-19$ \\
Mango Gusar pluton (1) & Two-mica granodiorite-granite & $37 \pm 0.8$ \\
Chingkang-la pluton (2) & Px-Hb-Bt granite & $34 \pm 1$ \\
Baltoro pluton (3) & Monzogranite-leucogranite & $21.4-25.5$ \\
Hunza dikes (4) & Granodiorite-leucogranite & Mid-Miocene \\
Sumayar pluton (5) & Leucogranite & $<37$ \\
& & \\
Higher Himalayas & & \\
A: India Himalayas & & 22.4 \\
Gangotri pluton (6) & Tourmaline-biotite leucogranite & \\
B: Nepal Himalayas & & $19-22.4$ \\
Manaslu pluton (7) & & \\
C: Nanga Parbat Haramosh Massif & Two-mica granite & $18-19$ \\
South Chichi pluton (8) & & 9.5 \\
Jutial pluton (9) & Leucogranite & 1.4 \\
Mazeno Pass pluton & Two-mica granite & \\
\hline
\end{tabular}

1, R. Parrish data in Searle, 1991; 2, Searle et al., 1989; 3, Searle et al., 1991 and Parrish and Tirrul, 1989; 4, Debon et al., 1987; 5, Searle et al., 1989 and Crawford and Searle, 1993; 6, Scaillet et al., 1990 and Harrison et al., 1997; 7, Coleman and Parrish, 1995 and Harrison et al., 1995; 8, Schneider et al., 1999b; 9, Schneider et al., 1999a.

pluton is the largest of all and is composed of monzogranite-leucogranite (Searle et al., 1992), which gives U$\mathrm{Pb}$ (zircon) age of 21.4-25.5 Ma (Parrish and Tirrul, 1989). The Hunza dikes comprise leucogranites, granodiorites, monzogranites, pegmatites and aplites. No radiometric age is available for these dikes. However, Debon et al. (1987) suggested a Mid-Miocene age. The Sumayar pluton, composed of a homogeneous leucogranite, is presumably younger than $37 \mathrm{Ma}$, because it cuts the metamorphic structures, which formed during the Barrovian type metamorphism with its culminating age of $37 \mathrm{Ma}$ (Searle et al., 1989; Crawford and Searle, 1993).
Majority of the Higher Himalayan post-collisional granites range from 19 to $24 \mathrm{Ma}$ in age and suggest younger plutonism (Harrison et al., 1997). The Gangotri and Manaslu plutons represent granitic rocks from the India and Nepal Himalayas, respectively. The Gangotri pluton comprises fine-grained tourmaline muscovite \pm biotite leucogranite (Scaillet et al., 1990) with $\mathrm{Th}-\mathrm{Pb}$ (monazite) age of $22.4 \mathrm{Ma}$ (Harrison et al., 1997). The Manaslu pluton, composed of two-mica granite with occasional tourmaline and garnet, yields 19 $\mathrm{Ma} \mathrm{U}-\mathrm{Pb}$ (Coleman and Parrish, 1995) and 22.4 Ma $\mathrm{Th}-\mathrm{Pb}$ (monazite) (Harrison et al., 1995) ages.

The Nanga Parbat-Haramosh Massif (NPHM) 
represents the westernmost extension of the Higher Himalayas in Pakistan. The South Chichi granite of the NPHM (Fig. 1) is composed of fine-grained leucogranite and gives $\mathrm{Th}-\mathrm{Pb}$ (monazite) ages of $18-19 \mathrm{Ma}$ (Schneider et al., 1999b). The Jutial and Mazeno Pass plutons, to the north of South Chichi granite, represent even much younger plutonic activities in the Nanga Parbat area. The Jutial pluton is largely undeformed, two-mica \pm tourmaline granite with $\mathrm{U}-\mathrm{Th}-\mathrm{Pb}$ (zircon and monazite) age of 9.5 Ma, whereas the Mazeno Pass pluton is composed of fine-grained, two-mica granite and yields $\mathrm{U}-\mathrm{Th}-\mathrm{Pb}$ (zircon and monazite) age of 1.4 Ma (Schneider et al., 1999a).

The $\mathrm{K}-\mathrm{Ar}$ biotite ages of Garam Chashma leucogranite range from 18 to $20 \mathrm{Ma}$. These ages are comparable to most of the Higher Himalayan post-collisional granites. The Higher Himalayan granites are characterized by tourmaline-muscovite-biotite mineral assemblage and restricted $\mathrm{SiO}_{2}$ range. The Garam Chashma two-mica leucogranite is also similar in mineral assemblage and chemistry to the Higher Himalayan granites (Murata et al., 1999 and Zafar et al., in prep.). In conclusion, the Garam Chashma leucogranite is younger than the other post-collisional granites in the TransHimalayas of northern Pakistan and is considered to be akin to the Higher Himalayan granites in terms of age, mineralogy and chemical characteristics.

\section{Acknowledgment}

Authors are indebted to Mr. S.H. Gauhar, Director General, Geological Survey of Pakistan, for his continuous support during the fieldwork in northern Pakistan. The manuscript was improved by valuable reviews and comments of Profs. S. Arai and A. Ishiwatari.

\section{References}

Coleman, M.E. and Parrish, R.R. (1995) Constraints on Miocene high-temperature deformation and anatexis within the Greater Himalayas from $\mathrm{U}-\mathrm{Pb}$ geochronology. Transactions American Geophysical Union (EOS), 76, F708.

Coward, M.P., Windley, B.F., Broughton, R.D., Luff, I.W., Petterson, M.G., Pudsey, C.J., Rex, D.C. and Khan, M.A. (1986) Collision tectonics in the NW Himalayas. In Collision Tectonics (Coward, M.P. and Ries, A.C. Eds.) Geological Society of London, Special Publication, 19, 203-219.

Crawford, M.B. and Searle, M.P. (1993) Collision-related granitoid magmatism and crustal structure of the Hunza Karakoram, North Pakistan. In Himalayan Tectonics (Treloar, P.J. and Searle, M.P. Eds.) Geological Society of London, Special Publication, 74, 53-68.
Debon, F., Le Fort, P., Dautel, D., Sonet, J. and Zimmerman, J.L. (1987) Granites of western Karakoram and northern Kohistan (Pakistan): A composite Mid-Cretaceous to Upper Cenozoic magmatism. Lithos, 20, 19-40.

Desio, A., Tongeorgi, E. and Ferrara, G. (1964) On the geological ages of some granites of the Karakoram-Hindukush and Badakhshan (Central Asia). 22 $2^{\text {nd }}$ International Geological Congress, New Delhi, 11-479-496.

Gaetani, M., Le Fort, P., Tanoli, S., Angiolini, L., Nicora, A., Sciunnach, D. and Khan, A. (1996) Reconnaissance geology in Upper Chitral, Baroghil and Karambar districts (northern Karakoram, Pakistan). Geological Rundsch, 85, 683-704.

Harrison, T.M., Lovera, O.M. and Grove, M. (1997) New insights into the origin of two contrasting Himalayan granite belts. Geology, 25, 899-902.

Harrison, T.M., McKeegan, K.D. and Le Fort, P. (1995) Detection of inherited monazite in Manaslu leucograntie by ${ }^{208} \mathrm{~Pb} /{ }^{232} \mathrm{Th}$ ion microprobe dating: Crystallization, age and tectonic significance. Earth and Planetary Science Letters, 133, 271-282.

Hildebrand, P.R., Noble, S.R., Searle, M.P., Parrish, R.R. and Shakirullah (1998) The tectonic significance of $24 \mathrm{Ma}$ crustal melting in the eastern Hindukush, Pakistan. Geology, 26, 871-874.

Itaya, T., Nagao, K., Inoue, K., Okada, T. and Ogata, A. (1991) Argon isotope analysis by a newly developed mass spectrometric system for $\mathrm{K}$-Ar dating. Mineralogical Journal, 15, 203-221.

Khan, T. (1986) Geology of the pegmatite belt in Chitral, Northwest Frontier Province Pakistan. Geological Survey of Pakistan, Information Release, 266, 1-16.

Murata, M., Zafar, M., Khan, T., Ozawa, H. and Nishimura, H. (1999) Major and trace element composition of postcollisional granitic rocks on the southern margin of Asian plate, north Pakistan. Research Bulletin of Natural Science, Naruto University of Education, 14, 15-28.

Nagao, K. and Itaya, T. (1988) K-Ar determination. Memoirs of Geological Society of Japan, 39, 5-21 (in Japanese).

Nagao, K., Nishio, H., Itaya, T. and Ogata, K. (1984) An age determination by $\mathrm{K}-\mathrm{Ar}$ method. Bulletin Hiruzen Research Institute, Okayama University of Science, 9, 1938.

Parrish, R.R. and Tirrul, R. (1989) U-Pb age of the Baltoro granite, northwest Himalaya, and implications for monazite $\mathrm{U}-\mathrm{Pb}$ systematics. Geology, 17, 1076-1079.

Petterson, M.G. and Windley, B.F. (1985) Rb-Sr dating of the Kohistan arc batholith in the Trans-Himalaya of $\mathrm{N}$. Pakistan and tectonic implications. Earth and Planetary Science Letters, 74, 54-75.

Pudsey, C.J. (1986) The Northern Suture, Pakistan: margin of a Cretaceous island arc. Geological Magazine, 123, 405-423.

Rowley, D.B. (1996) Age of initiation of collision between India and Asia: A review of stratigraphic data. Earth and Planetary Science Letters, 145, 1-13.

Scaillet, B., France-Lenord, C. and Le Fort, P. (1990) Badrinath-Gangotri plutons (Garhwal, India): petrological and geochemical evidence for fractionation processes in a high Himalayan leucogranite. Journal of Volcanology and Geothermal Research, 44, 163-188.

Schneider, D.A., Edwards, M.A., Zeitler, P.K. and Coath, C.D. 
(1999a) Mazeno Pass Pluton and Jutial Pluton, Pakistan Himalaya: age and implications for entrapment mechanisms of two granites in the Himalaya. Contributions to Mineralogy and Petrology, 136, 273-284.

Schneider, D.A., Edwards, M.A., Kidd, W.S.F., Zeitler, P.K. and Coath, C.D. (1999b) Early Miocene anatexis identified in the western syntaxis, Pakistan Himalaya. Earth and Planetary Science Letters, 167, 121-129.

Searle, M.P. (1991) Geology and tectonics of the Karakoram Mountain, John Wiley and Sons, New York, 358 p.

Searle, M.P., Crawford, M.B. and Rex, A.J. (1992) Field relations, geochemistry, origin, and emplacement of the Baltoro granite, Central Karakoram. Transactions Royal Society of Edinburgh, Earth Science, 83, 519-538.

Searle, M.P., Rex, A.J., Tirrul, R., Rex, D.C., Barnicoat, A. and Windley, B.F. (1989) Metamorphic, magmatic, and tectonic evolution of the central Karakoram in the BiafoBaltoro-Hushe regions of northern Pakistan. Geological Society of America, Special Paper, 232, 47-73.
Steiger, R. and Jäger, E. (1977) Subcommision on geochronology: convention on the use of decay constants in geo-and cosmo-chronology. Earth and Planetary Science Letters, 36, 359-362.

Tahirkheli, R.A.K. (1982) Geology of the Himalaya, Karakoram and Hindukush in Pakistan. Geological Bulletin, University of Peshawar, Pakistan, 15, 1-51.

Zafar, M., Murata, M., Khan, T., Ozawa, H. and Nishimura, H. (1998) Major and trace element composition of postcollisional, peraluminous Garam Chashma granite in Trans-Himalaya, northwestern Pakistan. 13th Himalaya-Karakoram-Tibet international workshop, Geological Bulletin, University of Peshawar, Special Issue, 31, 221-222.

Manuscript received; 1 June, 2000

Manuscript accepted ; 10 August, 2000 